\title{
PENGARUH PEMBERIAN BOKASHI PUPUK KANDANG TERHADAP PERTUMBUHAN DAN PRODUKSI BEBERAPA VARIETAS TANAMAN JAGUNG (Zea mays L)
}

\author{
Fivi Yedmi ${ }^{1}$, Susi Salhan, SP, MP² ${ }^{2}$ dan Zinatal hayati, SP² \\ program studi Agroteknologi Fakultas pertanian Universitas Islam Indragiri
}

\begin{abstract}
Research on the effect of giving Bokashi manure on the growth and production of several varieties of maize (Zea Mays $L$ ), this research was carried out in February to May 2012, which is located in the Salak river, Tempuling District, Indragiri Hilir Regency.

This study used a randomized block design (RCBD) factorially composed of 2 factors and 3 replications. Factor $B$ is Bokashi manure consisting of 4 levels, namely BO (without the provision of bokashi manure) B1 (5 tons / ha) and B2 (10 tons / ha), and B3 (15 tons / ha) while factor $\mathrm{v}$ is the variety consists of 3 levels, namely $\mathrm{V} 1$ (pioneer), V2 (N 35), and V3 (NT 10).

The parameters observed were plant height, the length of the seventh leaf, wet stover weight, dry stover weight, the weight of the cob planted samples, ear diameter, production per plot, and the weight of 100 seeds. Furthermore, the data obtained are processed statistically, if the $F$ count is greater than the $F$ table followed by a further test of the HSD tukey at the 5\% level.

The results showed that the interaction of bokashi pupu cage and varieties significantly affected the weight of cobs and production per plot, but did not significantly affect the plant height, the length of the seventh leaf, 1000 seeds. For the bokashi treatment, manure has a single effect on nayata on cob diameter, but it has no significant effect on plant height, seventh leaf length, wet stover weight, dry stover weight, cob weight, production per plot and weight of 1000 seeds., But not different marked with plant height, seventh leaf length, dry stover weight, and ear diameter. The best variety is NT10.
\end{abstract}

Keywords: Bokashi Varieties Manure, Corn Growth and Production.

Abstract
Penelitian tentang pengaruh pemberian Bokashi pupuk kandang terhadap
pertumbuhan dan produksi beberapa varietas tanaman jagung (Zea Mays L),
penelitian ini dilaksanakanan pada bulan februari sampai mei 2012, yang bertempat di
sungai Salak Kecamatan Tempuling Kabupaten Indragiri Hilir.
Penelitian ini menggunakan rancangan acak kelompok (RAK) yang disusun
secara faktorial yang terdiri dari 2 faktor dan 3 ulangan. Faktor B adalah Bokashi
pupuk kandang yang terdiri dari 4 taraf yaitu BO (tanpa pemberian bokashi pupuk
kandang) B1 ( 5 ton/ha) dan B2 (10 ton/ha), serta B3 (15 ton/ha) sedanglan faktor v
adalah varietas yang terdiri dari 3 taraf yaitu V1 (pioneer), V2 ( $\mathrm{N}$ 35), dan V3 (NT
10).
Parameter yang diamati adalah tinggi tanaman, panjang daun ke tujuh, berat
brangkasan basah, berat brangkasan kering, berat tongkol pertanaman sampel,
diameter tongkol, produksi per plot, dan berat 100 biji. Selanjutnya data yang
diperoleh diolah secara statistik, apabila $\mathrm{F}$ hitung lebih besar dari F tabel dilanjutkan
dengan uji lanjut tukey HSD pada taraf $5 \%$.
Hasil penelitian meenunjukan bahwa interaksi bokashi pupu kandang dan
varietas berpengaruh nyata terhadap berat tongkol dan produksi per plot, akan tetapi
tidak berpengaruh nyata terhadap terhadap tinggi tanaman, panjang daun ke tujuh,
1000 biji. Untuk perlakuan bokashi pupuk kandang secara tunggal berpengaruh nayata
terhadap diameter tongkol, akan tetapi tidak berpengaruh nyata terhadap tinggi
tanaman, panjang daun ketujuh, berat brangkasan basah, berat brangkasan kering,
berat tongkol, produksi per plot serta berat 1000 biji., akan tetapi tidak berbeda nyata


dengan tinggi tanaman, panjang daun ke tujuh, berat brangkasan kering, dan diameter tongkol. Varietas terbaik adalah NT10

Kata kunci: Bokashi Pupuk Kandang Varietas, Pertumbuhan dan Produksi Jagung. 


\section{PENDAHULUAN}

Tanaman jagung merupakan bahan makanan pokok kedua setelah padi, bahkan beberapa daerah merupakan bahan makanan pokok utama. Pada jagung juga terdapat kandungan gizi cukup tinggi, secara umum dalam 1000 gram berat kering jagung mengandungprotein 9,2 \% karbohidrat $80 \%$ lemak $39 \%$ kalori $335 \mathrm{kcl}$, air 12 gram, kalsium $10 \mathrm{mg}$, fosfor $256 \mathrm{mg}$, vitamin A 510 SI, vitamin B 0,038 gram (Anonimous 2002).

Produksi jagung di Kabupaten Indragiri Hilir pada tahun 2009 sebesar $10.631,98$ ton dengan luasan panen 4.949 ha. Pada tahun 2010 produksi jagung sebesar 9.430,22 ton, produksi ini mengalami penurunan, salah satu penyebab penurunan produksi jagung adalah menurunnya luas panen sebesar 4.082 ha (anonimous 2011). Teknologi sederhana yang dapat digunakan untuk mengatasi kendala pada tanah yang kurang subur adalah dengan pemberian pupuk organik. Penggunaan pupuk organik sudah diterapkan di kalangan petani karena dengan menggunakan pupuk organik mampu mempertahankan dan meningkatkan produksi dan tidak menimbulkan dampak negatif terhadap lingkungan maupun mengkonservasi dan mempertahankan produksi lahan.

Salah satu bentuk pupuk organik yang sekarang ini banyak digunakan adalah bokashi pupuk kandang. Bokashi pupuk kandang merupakan hasil fermentasi ekskresi dari sapi serta sisa makanan dari hewan dengan tambahan Efektif Mikroorganisme (EM4). Bokashi pupuk kandang mengandung unsur hara esensial yang dibutuhkan tanaman baik unsur makro maupun mikro, adapun komposisi unsur hara yang terdapat dalam bokashi pupuk kandang adalah $\mathrm{N}, \mathrm{P}, \mathrm{K}, \mathrm{Ca}, \mathrm{Mg}, \mathrm{S}, \mathrm{Zn}$, dan Bo sehingga unsur hara pada tanah lebih tersedia.

Menurut hasil penelitian Dahlan dan Kaharuddin (2007), penggunaan bokashi pupuk kandang 0-15 ton memberikan pengaruh nata terhadap tinggi tanaman, beert basah pipilan dan berat kering pipilan tanaman jagung. Peningkatan dosis bokashi pupuk kandang dapat meningkatkan hasil tanaman jagung karena bokashi pupuk kandang mengandung sejumlah unsur hara dan bahan organik yang dapat memperbaiki sifat fisik, kimia, dan biologi tanah.

Varietas hibrida lebih seragam dan mampu berproduksi lebih tinggi 15-20 $\%$ dari varietas bersari bebas. Selain itu, varietas hibrida menghasilkan biji yang lebih besar, tahan terhadap hama dan penyakit terutama penyakit bulai, mempunyai daya tumbuh yang mencapai $80 \%$ memiliki tongkol besar dan menarik, terisi penuh, klobot menutip sempurna yang menjamin hasil panen yang lebih baik (Anonimous 2011).

Dari permasalahan diatas maka penulis tertarik untuk melakukan penelitian yang berjudul Pengaruh Pemberian Bokashi Pupuk Kandang Terhadap pertumbuhan dan Produksi beberapa Varietas Tanaman Jagung (Zea mays $L)$.

\section{TINJAUAN PUSTAKA Jagung}

2.1 Klasifikasi dan Morfologi

Menurut Purwono dan Hartono (2006) jagung merupakan tanaman yang familiar bagi sebagian masyarakat, seiring dengan perkembangan teknologi ini, saat ini banyak beredar jenis jagung. Tanaman jagung termasuk dalam keluarga rerumputan dengan spesies Zea mays L secara umum klasifikasi dam sistematika tanaman jagung sebagai berikut :

Kingdom : Plantae (tumbuhtumbuhan)

Divisi

Spermatophyta

(tumbuhsn biji)

Subdivisi:

( berbiji tertutup)

Ordo rumputan)

Family

Genus

Spesies

: Graminae (rumput-

Angiospermae

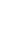

: Graminaecceae

Tanaman jagung banyak kegunaannya, hampir seluruh bagian tanaman dapat dimanfaatkan untuk berbagai macam keperluan. Batang dan daun tanaman yang muda digunakan untuk pakan ternak. Batang dan daun yang tua (setelah dipanen) dapat digunakan sebagai pupuk hijau atau kompos. $\mathrm{Di}$ daerah sentral tanaman jagung, batang dan daun jagung kering digunakan untuk kayu bakar. Buah muda digunakan sebagai 
bahan sayuran, pergedel, bakwan, dan sambal goreng. Bijijagung yang tua digunakan sebagai pengganti nasi, dibuat marning, brondong, roti (roti jagung), tepung dan sebagainya. Kegunaan lain juga sebagai bahan baku pembuatan pakan ternak dan industri bir, industri farmasi, dextrin termasuk untuk perekat dan indutri tekstil (Warisno, 1998).

Jagung termasuk tanaman berakar serabut yang terdiri dari tige tipe akar yaitu, akar seminal, akar adventif, dan akar udara. Akar seminar tumbuh dari radikula dan embrio, akar adventif disebut pula dengan akar tunjang, akar ini tumbuh dari buku paling bawah yaitu sekitar $4 \mathrm{~cm}$ di bawah permukaan tanah, perkembangan jagung tergantung dari varietas, kesuburan tanah, dan keadaan air tanah (Adisarwanto dan Wijayastuti, 2002).

Batang jagung tidak bercabang, berbentuk silinder dan terdiri dari beberapa ruas dan buku ruas dan akan muncul tunas yang berkembang menjadi tongkol, tinggi batang jagung tergantung varietas dan tempat penanaman umumna sekitar 60-300 $\mathrm{cm}$. Daun jagung terdiri dari 8-48 helai. Bunga jantan juga termasuk bunga yang tidak sempurna karena bunga jantan dan betina berada pada bunga yang berbeda. Bunga jantan terdapat diujung batang, adapun bunga betina terdapat diketiak daun ke 6 atau daun yang ke 8 dari bunga jantan. Tanaman jagung termasuk tanaman berumah satu dengan bunga betina terletak pada inforensen yang berbeda dengan bunga jantannya, tetapi masih terletak pada satu tanaman, bunga jantan tanaman jagung tersusun pada bulir yang rapat terletak pada ujung batang yang dinamakan malai atau tessel, bunga betina terletak pada ketiak daun dan beerbentuk tongkol, tanaman jagung memiliki batang herba (basah) batang berwarna hijau sampai keunguan, bentuk bulat dan penampang melintang, berukuran 2-2,5 cm batang jagung berbuku yang terbatasi oleh ruas ruas, jumlahnya bervariasi antara 10-40 ruas (Suprapto dan Marzuki, 2002)

\subsection{Varietas tanaman jagung}

Menurut adisarwanto dan widyaastuti (2002), secara umum asal benih jagung dapat dibedakan menjadi 2 varietas yaitu :

a. varietas Bersari Bebas

Benih varietas bersari bebas dapat digunakan terus menerus pada setiap penanaman. Benih berasal dari tongkol tanaman yang sesuai dengan varietas bersangkutan.

Secara umum benih varietas bersari bebas dibagi menjadi 2 golongan, yaitu varietas sintotik berasal dari campuran $2 \%$ atau lebih galur-galur perkawinan sendiri sedangkan varietas komposit berasal dari campuran beberapa plasma nutfah yang telah mengalami perkawinan acak.

Keuntungan menggunakan benih varietas ini adalah harganya relatif murah dan dapat ditanam beberapa kali tanpa mengalami degenerasi serius. Namun potensi hasil lebih rendah, dibanding benih varietas hibrida. Beberapa contoh varietas unggul bersari bebas adalah arjuna, rama, kalingga, wijaya, dan bisma.

b. varietas hibrida

Benih varietas hibrida merupakan benih dari varietas hibrida yang berasal dari keturunan pertama (F1) dan hasil persilangan varietas bersari bebas dan bersari bebas, varietas bersari bebas dan galur, atau galur dengan galur.

Varietas unggul hibrida merupakan andalan utama untuk menigkatkan produksi jagung dimasa datang karena keunggulannya. Keunggulan benih hibrida potensi hasilnya tinggi ( $>7$ ton/ha), pertumbuhannya lebih seragam dan tahan penyakit. Kelebihan benih hibrida ini diimbangi dengan haraganya yang relatif dengan menggunakan sidik ragam berdasarkan model linier.

\subsection{Pelaksanaan penelitian}

\subsubsection{Persiapan Bokashi}

Bahan bahan untuk ukuran 500 kg bokashi :

1. Pupuk kandang $=300 \mathrm{~kg}$

2. Dedak $=50 \mathrm{~kg}$

3. Sekam padi $\quad=150 \mathrm{~kg}$

4. Gula cair $\quad=200 \mathrm{ml}$

5. EM-4 $=500 \mathrm{ml}$

6.Air secukupnyamahal, untuk mendapatkan potensi hasil yang diharapkan, benih hibrida hanya digunakan untuk sekali tanam.

\subsection{Bokashi pupuk kandang}

Bokashi adalah jenis pupuk organik yang telah di fermentasikan dengan EM4. Sedangkan hasil 
fermentasi pupuk kandang dengan teknologi efektif mikroorganisme (EM) disebut bokashi pupuk kandang yang berfunsi untuk mengaktifkan mikroorganisme meningkatan kesuburan tanah secara biologi, menurunkan hama dan penyakit serta meningkatkan pertumbuhan dan produksi tanaman (Wididana, 1996). Kandungan unsur hara dalam setiap kilo gram bokashi pupuk kandang adalah sebagai berikut: Nitrogen 1,39 $\%, \mathrm{~N}-\mathrm{NH}_{4} \quad 0,86 \%, \mathrm{~N}-\mathrm{NO}_{3} 0,33 \%, \mathrm{C}-$ Organik 4,22\%, $\mathrm{P}_{2} \mathrm{O}_{3} 11,1 \mathrm{ppm}, \mathrm{Fe}$ 0,02 ppm, Ca142 \% (Hutagaol, 2011). Manfaat bokashi pupuk kandang adalah untuk meningkatkan pertumbuhan dan hasil tanaman, meningkatkan ketersediian unsur hara di dalam tanah, sserta dapat memperbbaiki sifat fisik tanah dan ketahanan tanaman terhadap serangan hama dan penyakit tanaman. Pada prinsipnya, peranan bokashi hampir sama dengan pupuk organik lainnya, seperti kompos, namun pada bokashi EM pengaruhnya dipercepat dengan adanya penambahan mikroorganisme efektif. Bokashi dapat digunakan 3-14 hari setelah perlakuan (fermentasi) bokashi dapat digunakan untuk meningkatkan perttumbuhan dan produksi tanaman meskipun bahan organik belum terurai seperti kompos. Bila bokashi dimasukkan kedalam tanah, bhan organiknya dapat digunakan sebagai pakan oleh mikroorganisme efektif untuk berkembang biak didalalm tanah, sekaligus sebagai tambahan persediaan unsur hara bagi tanaman (Anonimous, 2009).

\section{METODOLOGI PENELITIAN}

\subsection{Tempat dan Waktu}

Penelitian ini dilaksanakan pada February sampai mei 2012, yang bertempat di Sungai Salak Kecamatan Tempuling kabupaten Indragir Hilir Propinsi Riau.

\subsection{Bahan dan Alat}

Benih yang digunakan dalam penelitian ini adalah beberapa varietas jagung seperti Pioneer, N 35, NT 10. Pupuk yang dipakai antara lain : Urea, $\mathrm{TSP}$, dan KCL, kapur dolomit, bokashi pupuk kandang. Pestisida yang digunakan adalah Dithane $\mathrm{M}-45$ dan Decis 2,5 EC. Alat yang digunakan adalah cangkul, tugal, parang, meteran, tali plastik, garuk, timbangan, ember, pisau, amplop, label, sampel, plakat nama, hand spayer, alat tulis, dan kalkulator.

\subsection{Metode penelitian}

Penelitian dilaksanakan secara eksperimen dengan menggunakan Rancangan Acak Kelompok (RAK) yang disusun secara faktorial yaitu terdiri dari dua faktor dan 3 ulangan.

Faktor-faktor tersebut adalah

Faktor 1 : dosis bokashi yang terdiri dari 4 taraf

$\begin{array}{ll}\text { BO } & =\text { Tanpa perlakuan } \\ \text { B1 } & =5 \text { ton } / \text { hektar }=1,125 \mathrm{~kg} / \mathrm{plot} \\ \mathrm{B} 2 & =10 \text { ton } / \text { hektar }=2,25 \mathrm{~kg} / \mathrm{plot} \\ \mathrm{B} 3 & =15 \text { ton } / \text { hektar }=3,37 \mathrm{~kg} / \mathrm{plot}\end{array}$

Faktor II. Varitas jagung yang terdiri dari 3 taraf
V1 = Pioneer
$\mathrm{V} 2=\mathrm{N} 35$
V3 $=$ NT 10

Masing masing perlakuan perlakuan terdiri dari 3 ulangan sehingga jumlah seluruhnya adalah 36 unit percobaan. Data hasil penelitian dianalisis

Cara pembuatannya :

1. Larutkan EM-4 dan gula kedalam air. 2. Pupuk kandang, sekam padi, dan dedak dicampur secara merata.

3.Siramkan EM-4 secara perlahan lahan ke dalam adonan secara merata sampai kandungan air adonan mencapai $30 \%$.

4. Bila adonan dikepal dengan tangan, air tidak menetes dan bila dikepalan tangan dilepas maka adonan susah pecah (megar).

5. Adonan digundukkan diatas ubin yang kering dengan ketinggian minimal $15-20 \mathrm{~cm}$.

6. kemudian ditutup dengan karung goni selama 4 hari.

7. pertahankan gundukkan adonan maksimal $5^{\circ} \mathrm{C}$ turunkan suhunya dengan membolak balik, lalu tutup dengan goni.

8. pengecekkan suhu sebaiknya dilakukakan dalam setiap 5 jam sekali. 9. Setelah 4 hari bokashi sudah bisa digunakan (Nasir, 2005).

\subsubsection{Persiapan lahan}

Lahan yang digunakan dibersihkan dari sisa sisa tanaman dan gulma, kemudian dilakukan pengolahan tanah sedalam 20-30 cm, dibuat plot dengan ukuran $1,5 \times 1,5$ meter, jarak antara ulangan 0,5 meter dan jarak antar plot dalam satu ulangan 0,3 meter. 


\subsubsection{Pemberian perlakuan}

Pemberian bokashi pupuk kandang dilakukan 1 minggu sebelum tanam dengan tujuan agar bokashi pupuk kandang beraksi dengan tanah. Dosis yang digunakan sesui dengan perlakuan, dengan cara diaduk rata dengan tanah.

\subsubsection{Penanaman}

Penanaman biji dilakukan secara tunggal dengan kedalaman 3 $\mathrm{cm}$, diisi dua benih jagung per lubang tanam, kemudian lubang tugal ditutup kembali. Jarak tanam yang digunakan $75 \times 25 \mathrm{~cm}$ sehingga ditemukan populasi 12 tanaman per plot. Penanaman dilakukan 2 minggu setelah pengapuran.

\subsubsection{Pemupukan}

Pemberian pupuk anorganik adalah pupuk Urea $200 \mathrm{~kg} / \mathrm{ha}$ (45 gr/plot), TSP $100 \mathrm{~kg} / \mathrm{ha}$ (2,25 gr/plot), $\mathrm{KCL} 50 \mathrm{~kg} / \mathrm{ha}$ (11.25 gr/plot). Pemberian pupuk dilakukan secara tugal untuk setiap tanaman dengan jarak $7 \mathrm{~cm}$ dari lubang tanam dan kedalaman lebih kurang $5 \mathrm{~cm}$. Pemupukan dilakukan bersamaan dengan waktu penanaman, pupuk Urea diberikan dua tahap yaitu pada waktu $1 / 2$ bagian dari dosis dan sisanya saat tanaman berumur 30 hari setelah tanam.

\subsubsection{Pemeliharaan}

\subsubsection{Penyulaman}

Penyulaman dilakukan pada saat tanaman berumur satu minggu setelah tanam dengan menggunakan benih yang disediaakan untuk penyulaman.

\subsubsection{Penjarangan}

Penjarangan dilakukan setelah tanaman berumur 2 minggu. Penjarangan dilakukan dengan memotong salah satu dari dua tanaman yang tumbuh, tanaman yang ditinggal adalah satu tanaman yang terbaik relatif seragam.

\subsubsection{Penyiraman}

Penyiraman dilakukan satu kali sehari, dilakukan pada sore hari tergantung kondisi lingkungan. Penyiraman dengan menggunakan gembor, jika turun hujan penyiraman tidak dilakukan, penyiraman dilakukan sampai tongkol jagung muncul.

\subsubsection{4 Penyiangan \\ dan \\ Pembumbunan}

Penyiangan dilakukan dengan cara membersihkan gulma yang terdapat di areal tanaman jagung secara manual dan dilanjutkan dengan pembumbunan pada setiap plot. Pembumbunan dilakukan dengan menaikkan tanah pada daerah perakaran jagung jepangkal tanaman. Pembumbunan bertujuan untuk memperkuat berdirinya tanaman dan memperbiaki aerase tanah. pembumbunan dilakukan saat tanaman berumur 25 hari setelah tanam.

\subsubsection{Panen}

Panen dilakuan setelah bij pada tongkol mencapai kriteria panen dengan tanda tanda daun mengering, kelobot berwarna kuning, biji kering dan mengkilat, serta bila ditekan dengan kuku tidak meninggalkan bekas. Panen dilakukan dengan mengambil tongkol dari batangnya dengan cara mematahkan.

\subsection{Pengamatan}

\subsubsection{Tinggi tanaman (cm)}

Pengukuran tinggi tanaman dilakukan setelah bunga jantan mekar, tinggi tanaman diukur dari permukaan tanah sampai ujung bunga jantan, pengamatan ini dilakukan pada tanaman sampel yang diambil secara acak.

\subsubsection{Panjang daun ketujuh (cm)}

Pengukuran panjang daun ketujuh dilakukan degan cara menghitung jumlah daun dari atas kebawah. Kemudian dilakukan pengukuran mulai dari pangkal daun hingga ujung daun, pengukuran dilakukan pada saat tanaman berumur 50 hari setelah tanam (akhir fase vegetatif), pengamatan ini dilakukan pada tanaman sampel yang sama dengan parameter tinggi tanaman.

3.5.3. Berat brangkasan basah (gram)

Pengamatann ini dilakukan dengan cara menimbang berat brangkasan basah batang, daun dan akar masing masing tanaman sampel. Pengamatan ini dilakukan pada masa akhir vegetatif.

\subsubsection{Berat brangkasan kering (gram)}

Pengamatan dilakukan dengan menimbanng brangkasan kering (batang, daun, dan akar) masing masing tanaman yang telah dijemur di bawah sinar matahari selama $2 \times 24$ jam.

\subsubsection{Berat tongkol per tanaman sampel (kg) \\ Pengamatan berat tongkol} dilakukan dengan cara menimbang 
tongkol jagung tanpa klobot setelah panen.

\subsubsection{Diameter tongkol (cm)}

Pengukuran diameter tongkol tanaman dilakukan setelah panen denngan memotong menjadi 2 bagian, kemudian dilakukan pengukuran diameter tongkol dengan menggunakan jangka sorong.

\subsubsection{Produksi per plot (kg)}

Pengamatan dilakukan dengan menimbang berat tongkol jagung per plot setelah panen. Populasi tanaman berjumlah 12 tanaman, 2 tanaman dicabut untuk pengamatan berat brangkasan basah dan brangkasan kering. Sisa tanaman sebanyak 10 tanaman digunakan untuk parameter produksi per plot.

\subsubsection{Berat 1000 biji (gr)}

Pengamatan dilakukan dengan menimbang 1000 biji jagung pipilan kering yang diambil secara acak dari masing masing tanaman sampel setelah bijji dikeringkan di bawah sinar matahari selam 3 hari. Dalm kondisi panas matahari normal pengeringan padi dan jagung untuk memenuhi kadar air menjadi 14-15 \% diperlukan waktu antara 2-3 hari (Faragri. Blogasme.com)

\section{HASIL DAN PEMBAHASAN \\ 4.1 Tinggi Tanaman}

Dari data pengamatan tinggi tanaman setelah di analisis sidik ragam menunjukan bahwa interaksi bokashi pupuk kandang dan varietas tidaj berpengaruh nyata terhadap tinggi tanaman, perlakuan bokashi pupuk kandang dan varietas secara tunggal tidak berpengaruh nyata terhadap tinggi tanaman. Hasil analisis statistik yang diuji lanjut dengan tukey HSD pada taraf $5 \%$ dapat dilihat pada tabel 2.

Tabel 2. Rata rata tinggi tanaman (cm) pada perlakuan bokashi pupuk kandang dan beberapa varietas tanaman jagung

\begin{tabular}{|c|c|c|c|c|}
\hline \multirow{2}{*}{$\begin{array}{l}\text { Bokas } \\
\text { hi } \\
\text { pupuk } \\
\text { kanda } \\
\text { ng } \\
\text { (ton/h } \\
\text { a) }\end{array}$} & \multicolumn{3}{|c|}{ Tinggi tanaman } & \multirow{2}{*}{$\begin{array}{l}\text { Rata } \\
\text { rata }\end{array}$} \\
\hline & $\begin{array}{l}\text { pione } \\
\text { er }\end{array}$ & N 35 & NT 10 & \\
\hline 0 & $\begin{array}{l}252.1 \\
7\end{array}$ & $\begin{array}{l}255 . \\
17\end{array}$ & $\begin{array}{l}250.0 \\
0\end{array}$ & $\begin{array}{l}252 . \\
44 a\end{array}$ \\
\hline
\end{tabular}

\begin{tabular}{|l|l|l|l|l|}
\hline 5 & $\begin{array}{l}249.0 \\
0\end{array}$ & $\begin{array}{l}255 . \\
00\end{array}$ & $\begin{array}{l}259.0 \\
0\end{array}$ & $\begin{array}{l}254 . \\
50 \mathrm{a}\end{array}$ \\
\cline { 1 - 4 } 10 & 264.0 & 249. & 258.5 & 257. \\
& 0 & 00 & 0 & $61 \mathrm{a}$ \\
\cline { 1 - 4 } 15 & 259.0 & 246. & 260.8 & 258. \\
& 0 & 00 & 3 & $28 \mathrm{a}$ \\
\cline { 1 - 3 } $\begin{array}{l}\text { Rata } \\
\text { rata }\end{array}$ & $\begin{array}{l}\text { 256. } \\
\text { 17 A }\end{array}$ & $\begin{array}{l}\text { 251. } \\
\text { 63 A }\end{array}$ & $\begin{array}{l}\text { 259. } \\
\text { 33 A }\end{array}$ & \\
\cline { 1 - 3 } & & &
\end{tabular}

Keterangan : angka angka pada kolom da baris yang diikuti oleh huruf kecil yang tidak sama pada kolom yang sama berbeda nyata pada taraf 5\% Tukey HSD

\subsection{Panjang daun ketujuh}

Dari data peengamatan panjang daun ketujuh setelah dianalisis sidik ragam menunjukan bahwa interaksi bokashi pupuk kandang dan varietas tidak berpengaruh nyata terhadap panjang daun ke tuuh, perlakuan bokashi pupuk kandang dan varietas secara tunggal tidak memberikan pengaruh nyata terhadap panjang daun ke tujuh.

Tabel 3. Rata rata panjang daun ke tujuh $(\mathrm{cm})$ pada perlakuan bokashi pupuk kandang dan beberapa varietas tanaman jagung

\begin{tabular}{|c|c|c|c|c|}
\hline \multirow{2}{*}{$\begin{array}{l}\text { Bokas } \\
\text { hi } \\
\text { pupuk } \\
\text { kanda } \\
\text { ng } \\
\text { (ton/h } \\
\text { a) }\end{array}$} & \multicolumn{3}{|c|}{ Varietas } & \multirow{2}{*}{$\begin{array}{l}\text { Rata } \\
\text { rata }\end{array}$} \\
\hline & $\begin{array}{l}\text { pione } \\
\text { er }\end{array}$ & N 35 & $\begin{array}{l}\text { NT } \\
10\end{array}$ & \\
\hline 0 & $\begin{array}{l}105.6 \\
7\end{array}$ & $\begin{array}{l}96.1 \\
7\end{array}$ & 97.83 & $\begin{array}{l}99.89 \\
a\end{array}$ \\
\hline 5 & 71.63 & $\begin{array}{l}67.9 \\
0\end{array}$ & 91.83 & $\begin{array}{l}77.12 \\
a\end{array}$ \\
\hline 10 & 74.63 & $\begin{array}{l}98.3 \\
3\end{array}$ & 99.50 & $\begin{array}{l}90.82 \\
\mathrm{a}\end{array}$ \\
\hline 15 & $\begin{array}{l}107.6 \\
7\end{array}$ & $\begin{array}{l}99.1 \\
7\end{array}$ & $\begin{array}{l}101.1 \\
7\end{array}$ & \multirow[t]{2}{*}{$\begin{array}{l}102.6 \\
7 a\end{array}$} \\
\hline $\begin{array}{l}\text { Rata } \\
\text { rata }\end{array}$ & $\begin{array}{l}89.9 \\
\text { O A }\end{array}$ & $\begin{array}{l}90.3 \\
9 \mathrm{~A}\end{array}$ & $\begin{array}{l}97.5 \\
8 \mathrm{~A}\end{array}$ & \\
\hline
\end{tabular}

Keterangan: Angka angka pada kolom dan baris yang diikuti oleh huruf kecil huruf yang tidak sama pada kolom yang sama berbeda nyata paada taraf 5\% Tukey HSD

\subsection{Berat brangkasan basah (gram)}

Dari data pengamatan berat brangkasan basah setelah di analisis sidik ragam menunjukan bahwa 
interaksi bokashi pupuk kandang dan varietas tidak berpengaruh nyata terhadap berat brangkasan basah, perlakuan bokashi pupuk kandang secara tunggal tidak berpengaruh nyata terhadap berat brangkasan basah, akan tetapi perlakuan varietas secara tunggal memberikan pengaruh nyata terhadap berat brangkasan basah.

\subsection{Berat Brangkasan Kering}

Dari data pengamatan berat brangkasan kering setelah di analisis sidik ragam menunnjukan bahwa interaksi bokashi pupuk kandang dan varietas tidak berpengaruh nyata terhadap berat brangkasan kering. Perlakuan bokashi kandang dan varietas secara tunggal tidak memberikan pengaruh nyata terhadap berat brangkasan kering.

Tabel 5. Rata rata berat brangkasan kering pada perlakuan bokashi pupuk kandang dan beberapa varietas tanaman jagung

\begin{tabular}{|c|c|c|c|c|}
\hline \multirow{3}{*}{$\begin{array}{l}\text { Bokas } \\
\text { hi } \\
\text { pupuk } \\
\text { kanda } \\
\text { ng } \\
\text { (ton/h } \\
\text { a) }\end{array}$} & \multicolumn{3}{|c|}{ Varietas } & \multirow{2}{*}{$\begin{array}{l}\text { Rata } \\
\text { rata }\end{array}$} \\
\hline & $\begin{array}{l}\text { pione } \\
\text { er }\end{array}$ & N 35 & NT 10 & \\
\hline & \multicolumn{4}{|l|}{ gram } \\
\hline 0 & $\begin{array}{l}200.0 \\
0\end{array}$ & $\begin{array}{l}208.3 \\
3\end{array}$ & $\begin{array}{l}158.3 \\
3\end{array}$ & $\begin{array}{l}188 . \\
89 a\end{array}$ \\
\hline 5 & $\begin{array}{l}175.0 \\
0\end{array}$ & $\begin{array}{l}191.6 \\
7\end{array}$ & $\begin{array}{l}216.6 \\
7\end{array}$ & $\begin{array}{l}194 . \\
44 \mathrm{a}\end{array}$ \\
\hline 10 & $\begin{array}{l}183.3 \\
3\end{array}$ & $\begin{array}{l}208.3 \\
3\end{array}$ & $\begin{array}{l}225.0 \\
0\end{array}$ & $\begin{array}{l}205 . \\
56 a\end{array}$ \\
\hline 15 & $\begin{array}{l}183.3 \\
3\end{array}$ & $\begin{array}{l}233.3 \\
3\end{array}$ & $\begin{array}{l}250.0 \\
0\end{array}$ & \multirow[t]{2}{*}{$\begin{array}{l}222 . \\
22 a\end{array}$} \\
\hline $\begin{array}{l}\text { Rata } \\
\text { rata }\end{array}$ & $\begin{array}{l}185 . \\
42 A\end{array}$ & $\begin{array}{l}210 . \\
42 A\end{array}$ & $\begin{array}{l}212 . \\
50 \text { A }\end{array}$ & \\
\hline
\end{tabular}

Keterangan : Angka angka pada kolom dan baris yang diikuti oleh huruf kecil yang tidak sama pada kolomyang sama berbeda nyata pada taraf 5\% Tukey $H S D$

Dari tabel 5 diketahui nahwa bobot brangkasan kering tertinggi di peroleh pada perlakuan bokashi pupuk kandang 15 ton/ha yaitu 222,22 g, sedangkan berat brangkasan kering terendah di peroleh pada perlakuan tanpa pemberian bokashi pupuk kandang yaitu $188,89 \mathrm{~g}$. Walaupun tidak berbeda secara statistik, tetapi secara angka dapat dilihat bahwa 15 ton/ha bokashi pupuk kandang mampu meningkatkan berat brangkasan kering sebesar 33,33 g dibandingkan dengan tanpa pemberian bokashi pupuk kandang.

\subsection{Berat tongkol (gram)}

Tabel 6. Rata rata berat tongkol pada perlakuan bokashi pupuk kandang dan beberapa varietas tanaman jagung

\begin{tabular}{|c|c|c|c|}
\hline \multirow{2}{*}{$\begin{array}{l}\text { Bokashi } \\
\text { Pupuk } \\
\text { kandang } \\
\text { (Ton/ha) }\end{array}$} & \multicolumn{3}{|c|}{ Berat tongkol } \\
\hline & Pioneer & N 35 & N10 \\
\hline \multicolumn{4}{|l|}{ gram } \\
\hline $\begin{array}{l}0 \\
5 \\
10 \\
15\end{array}$ & $\begin{array}{l}229.17 \\
A B \\
193.33 \\
A B \\
263.50 \\
A B \\
171.67 B\end{array}$ & $\begin{array}{l}241.67 \\
A B \\
275.00 \\
A B \\
263.50 \\
A B \\
284.17 \\
A B\end{array}$ & $\begin{array}{l}261.50 A B \\
284.00 A B \\
275.67 A B \\
358.67 A\end{array}$ \\
\hline
\end{tabular}

Keterangan : Angka angka pada kolom dan baris yang diikuti oleh huruf kecil yang tidak sama pada kolom yang sama berbeda nyata dari taraf 5\% Tukey HSD

Dari tabel 6 pada bokashi pupuk kandang 15 ton/ha pada varietas pioneer menunjukan interaksi berbeda nyata dengan NT 10, tetapi tidak menunjukan interaksi berbeda nyata dengan varietas N 35. Dari tabel diatas dapat disimpulkan bahwa pemberian bokashi pupuk kandang 15 ton/ha mampu meningkatkan berat tongkol jagung, hal ini berkaitan dengan berat brangkasan kering jagung yang menunjukan dengan pemberian bokashi pupuk kandang 15 ton/ha mampu memberikan berat brangkasan kering tertingi dengan perlakuan lainnya.

4.6 Diameter Tongkol (cm)

\begin{tabular}{|l|l|l|l|l|}
\hline \multirow{2}{*}{$\begin{array}{l}\text { Bokashi } \\
\text { pupuk } \\
\text { kandang } \\
\text { (Ton/ha) }\end{array}$} & \multicolumn{2}{|l|}{ varietas } & Rata-rata \\
\cline { 2 - 4 } & er & $\begin{array}{l}\mathrm{N} \\
35\end{array}$ & $\begin{array}{l}\text { NT } \\
10\end{array}$ & \\
\hline $\mathrm{cm}$ & 4.56 & 5.00 & 5.23 & $4.93 \mathrm{~b}$ \\
0 & 5.03 & 5.03 & 5.60 & $5.22 \mathrm{~b}$ \\
5 & 4.46 & 5.43 & 5.83 & $5.24 \mathrm{~b}$ \\
10 & 6.86 & 6.46 & 7.26 & $6.86 \mathrm{a}$ \\
15 &
\end{tabular}




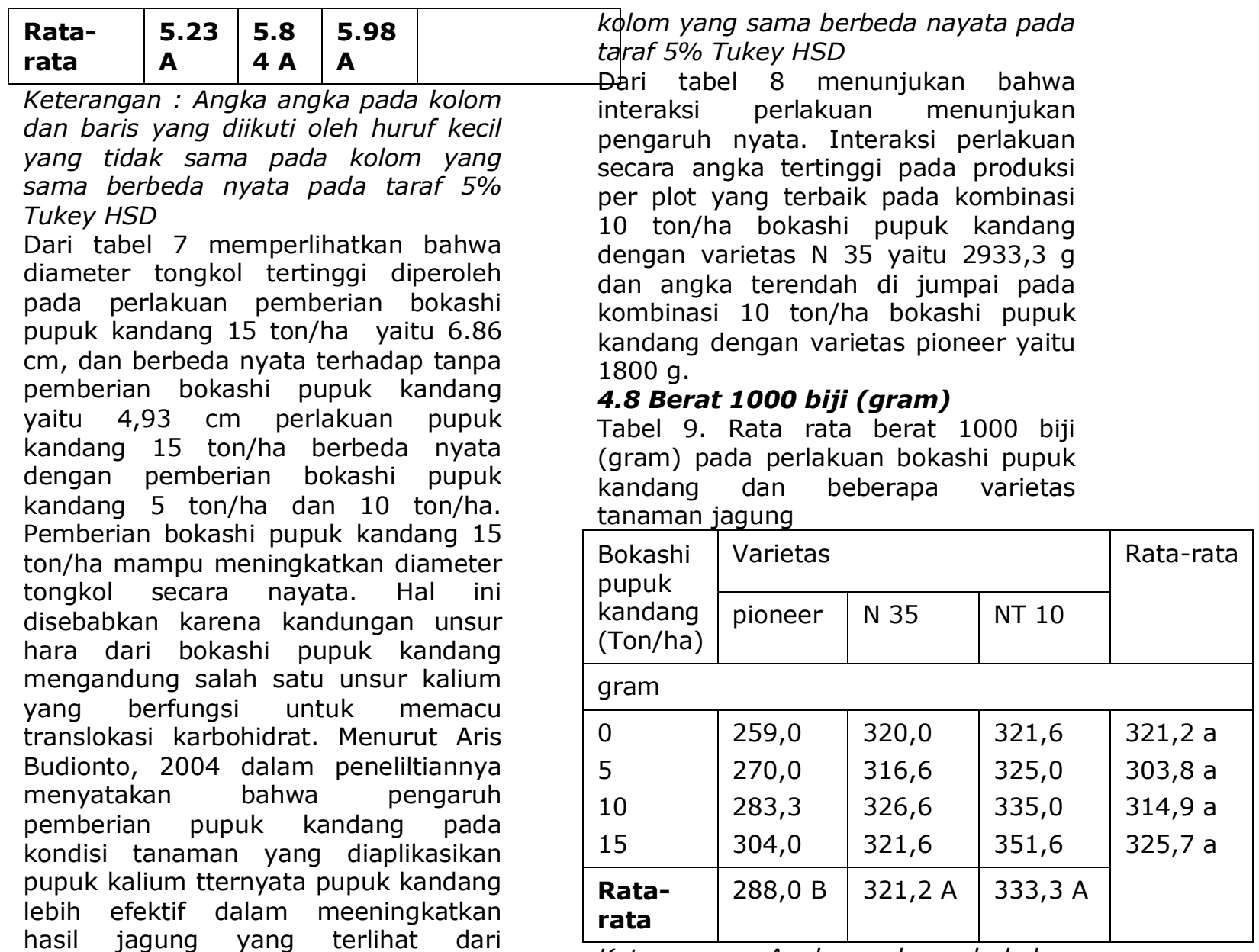

hasil jagung yang terlihat dari peningkatan diameter tongkol, jumlah baris per tongkol dan bobot tongkol per tanaman.

\subsection{Produksi per plot}

Tabel 8. Rata rata produksi per plot pada perlakuan Bokashi pupuk kandang dan beberapa varietas tanaman jagung

\begin{tabular}{|c|c|c|c|}
\hline \multirow{2}{*}{$\begin{array}{l}\text { Bokashi } \\
\text { pupuk } \\
\text { kandang } \\
\text { (Ton/ha) }\end{array}$} & \multicolumn{3}{|l|}{ Varietas } \\
\hline & Pioneer & N 35 & NT 10 \\
\hline \multicolumn{4}{|l|}{ gram } \\
\hline 0 & $\begin{array}{l}1850.0 \\
B C\end{array}$ & $\begin{array}{l}2700.0 \\
A B C\end{array}$ & $\begin{array}{l}2766.7 \\
A B\end{array}$ \\
\hline 5 & $\begin{array}{l}22.00 \\
A B C\end{array}$ & $\begin{array}{l}2466.7 \\
A B C\end{array}$ & $\begin{array}{l}2700.0 \\
A B C\end{array}$ \\
\hline 10 & 1800.0 & $\begin{array}{l}2933.3 \\
A\end{array}$ & $\begin{array}{l}2866.7 \\
A\end{array}$ \\
\hline 15 & $\begin{array}{l}2550.0 \\
A B C\end{array}$ & $\begin{array}{l}2666.7 \\
A B C\end{array}$ & $\begin{array}{l}2600.0 \\
A B C\end{array}$ \\
\hline
\end{tabular}

Keterangan: Angka angka pada kolom dan baris yang diikuti oleh huruf diatas kecil yang tidak sama pada

Keterangan : Angka angka pada kolom dan baris yang diikuti oleh huruf kecil yang tidak sama pada kolom yang sama berbeda nyata pada taraf 5\% Tukey HSD

Dari tabel 9 diatas dapat dilihat bahwa berat 1000 biji tertinggi di peroleh pada perlakuan bokashi pupuk kandang 15 ton/ha yaitu $325,7 \mathrm{~g}$ dan berat $1000 \mathrm{bji}$ terendah diperoleh pada perlakuan 5 ton/ha yaitu $303,8 \mathrm{~g}$. Dengan penambahan bokashi pupuk kandang 15 ton/ha mampu meningkatkan berat $1000 \mathrm{biji}$, dimana pada peerlakuan 15 ton/ha memperlihatkan angka tertinggi walaupun tidak berbeda nyata secara statistik. 15 tonbokashi pupuk kandang mampu meningkatkan beraat 1000 biji sebesar disebabkan oleh ketersediaannya unsur hara makro dan mikro yang terdapat di dalam bokashi pupuk kandang. Hal ini berkaitan dengan adanya unsur nitrogen, fosfor, dan kalium, dimana unsur ini berguna untuk pertumbuhan dan produksi tanaman jagung tersebut karena mempengaruhi proses fisiologis tanaman. 


\section{KESIMPULAN DAN SARAN 5.1 Kesimpulan}

Berdasarkan hasil penelitian yang telah dilakukan, maka didapat kesimpulan sebagai berikut :

1. pemberian bokashi pupuk kandang menunjukan pengaruh yang berbeda nyata terhadap diameter tongkol. Pemberian bokashi pupuk kandang terbaik untuk parameter diameter tongkol terdapat pada pemberian bokashi pupuk kandang 15 ton/ha.

2. Varietas menunjukan pengaruh yang berbeda nyata terhadap berat brangkasan basah, berat tongkol, produksi peer plot, dan berat 1000 biji. Varietas terbaik untuk parameter brangkasan basah berat tongkol, produksi per plot, dan berat 1000 biji adalah NT 10.

3. Interaksi antara bokashi pupuk kandang dan varietas pengaruh yang nyata terhadap berat tongkol dan produksi per plot.

\subsection{Saran}

Berdasarkan penelitian yang dilakukan penulis memberikan saran bahwa :

1. Penanaman jagung sebaiknya diberikan bokashi pupuk kandang 15 ton/ha dan varietas NT 10.

2. Untuk penelitian penelitian berikutnya disarankan agar meningkatkan dosis bokashi pupuk kandang yang diberikan agar hasil lebih baik

\section{DAFTAR PUSTAKA}

(1). Adirsarwanto, dan Widyaastuti, Y.E, . 2002. Meningkatkan produksi jagung di lahan kering, sawah, dan pasang surut. Penebar swadaya. Jakarta.

(2). Anonimous. 2002. Sweet cron body corn, Penebar Swadaya. Jakarta.

Anonimous, 2009.

(3). http;/www.kelompok tani .webs.com Teknik pembuatan pupuk organik.

(4). Anonimous. 2011. Berita Resmi Statistik Kabupaten Indragiri Dinas Perkebunan juli 2011

(5). Anonimous. 2011. http:/balitsereal.litbag.deptan.go.id Dwijosaputra, $1980 . \quad$ Pengantar Fisiologi Tumbuhan. Penerbit PT. Gramedia. Jakarta.
(6). Fragri.blogasme.com diakses tanggal 20 april 2013.

(7). Hutagaol. J., Pemberian Bokashi Pupuk kandang dan Gibberelin pada Tanaman Tomat (Lycopersicum esculentum, mill) Di polybag (skripsi) Fakultas Pertanian Universitas Islam Riau (UIR). Pekanbaru.

(8). Nasir, 2005. Pengaruh Penggunaan Pupuk Bokashi Pada Pertumbuhan dan Produksi Padi Palawijaya dan Sayuran. Publikasi. Jakarta.

(9). Suprapto dan Marzuki, R,. 2002. Bertanam 
Jagung, Penebar Swadaya. Jakarta. 